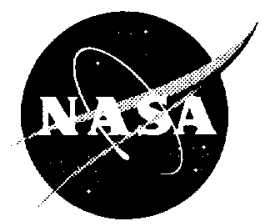

\title{
On-Board Propulsion System Analysis of High Density Propellants
}

Steven J. Schneider

Lewis Research Center, Cleveland, Ohio

Prepared for the

34th Joint Propulsion Conference and Exhibit

cosponsored by AIAA, ASME, SAE, and ASEE

Cleveland, Ohio, July 13-15, 1998

National Aeronautics and

Space Administration

Lewis Research Center 
Available from

NASA Center for Aerospace Information 7121 Standard Drive Hanover, MD 21076

Price Code: A03
National Technical Information Service 5285 Port Royal Road Springfield, VA 22100 Price Code: $\mathrm{A} 03$ 


\title{
On-Board Propulsion System Analysis of High Density Propellants
}

\author{
Steven J. Schneider \\ National Aeronautics and Space Administration \\ Lewis Research Center \\ Cleveland, Ohio 44135
}

\begin{abstract}
$\underline{\text { Abstract }}$
The impact of the performance and density of on-board propellants on science payload mass of Discovery Program class missions is evaluated. A propulsion system dry mass model, anchored on flightweight system data from the Near Earth Asteroid Rendezvous mission is used. This model is used to evaluate the performance of liquid oxygen, hydrogen peroxide, hydroxylammonium nitrate, and oxygen difluoride oxidizers with hydrocarbon and metal hydride fuels. Results for the propellants evaluated indicate that the state-of-art, Earth storable propellants with high performance rhenium engine technology in both the axial and attitude control systems has performance capabilities that can only be exceeded by liquid oxygen/hydrazine, liquid oxygen/diborane and oxygen difluoride/diborane propellant combinations. Potentially lower ground operations costs is the incentive for working with nontoxic propellant combinations.
\end{abstract}

\section{Introduction}

New NASA planetary exploration missions are being conducted under the Discovery Program'. One of the goals of this program is to substantially reduce total mission cost while improving performance, through the use of new technology and the control of design/development and operations costs. Funding constraints require the use of a medium (Delta II) class or smaller launch service. The performance and cost of the on-board propulsion system on these missions can be a significant contributor to the program goal of obtaining the highest possible science value per unit cost.

Hypergolic propellants such as nitrogen tetroxide (NTO), monomethylhydrazine (MMH), and anhydrous hydrazine ( $\mathrm{N} 2 \mathrm{H} 4$ ) have been the propellants of choice for on-board propulsion on satellites for more than 30 years. These propellants have a high demonstrated system reliability due to flight heritage, system simplicity, and because they ignite readily on contact with one another (hypergolicity). They are classified as "Earth Storable" due to their room temperature normal boiling points. These propellants are highly toxic, however, and their use can entail high operating costs due to increasingly more stringent environmental regulations making it difficult to store, transport, and handle them.

* Acrospace Engineer, Senior Member AIAA 
The purpose of this paper is to evaluate the mission performance of alternative space storable propellants, especially those fuels selected from among the less toxic, high density, hydrocarbons along with space storable oxidizers. The overall propellant density of each fuel and oxidizer combination is calculated for comparison, in order to draw conclusions on the relative value of density vs. performance of propellant combinations. The mission selected for the comparison of alternative propellants is launched on a Delta II-7925. The propellants chosen have low freezing points to minimize thermal control requirements on the satellite.

\section{Propulsion System Dry Mass Model}

In order to evaluate the mission performance of various propellants on a Discovery Program ${ }^{1}$ class satellite, a propulsion system dry mass model is assembled and anchored on the Near-Earth Asteroid Rendezvous (NEAR) propulsion system ${ }^{2}$. In the model, the mass injected by the launch vehicle is $805 \mathrm{~kg}$. The NEAR propulsion system supplies an axial $\Delta \mathrm{V}=1176$ $\mathrm{m} / \mathrm{sec}$ at a specific impulse of $313 \mathrm{sec}$ using NTO and $\mathrm{N} 2 \mathrm{H} 4$ propellants. $\mathrm{A} \Delta \mathrm{V}=184 \mathrm{~m} / \mathrm{sec}$ for attitude control is supplied by monopropellant $\mathrm{N} 2 \mathrm{H} 4$ at a specific impulse of $234 \mathrm{sec}$. The science payload mass on the mission is reported to be $55 \mathrm{~kg}$ in Reference 3 . The GN\&C, and its associated structure is assumed constant in the model comparisons and only the science payload varies with propulsion system performance. The propulsion system model includes models for the propellant and pressurant tanks plus masses for the feed system components and thrusters.

A generalized dry mass model for conventional propellant tanks was developed in Reference 4 and was compared to spherical tanks in the range of 0.0056 to $0.80 \mathrm{~m}^{3}$ volume. This model is used in this paper and is given by the following equation:

$$
M_{\operatorname{tank}}=1.2+K \rho V\left[\left(\frac{P}{\sigma}+1\right)^{3}-1\right] k g
$$

where the constant 1.2 is the minimum mass of reinforsed inlet and outlet fittings and $\mathrm{K}$ is a tank type factor

$$
\begin{aligned}
\mathrm{K}= & 1.45 \text { for surface tension tanks } \\
= & 1.75 \text { for diaphragm tanks } \\
= & 1.1 \text { for shell tanks } \\
\rho= & \text { tank material density }\left(\mathrm{kg} / \mathrm{m}^{3}\right) \\
\mathrm{V}= & \text { tank volume }\left(\mathrm{m}^{3}\right) \\
\mathrm{P}= & \text { maximum operating pressure }(\mathrm{kPa}) \\
\sigma= & \text { tank material ultimate tensile stress } \\
& (\mathrm{kPa})
\end{aligned}
$$

Using this equation the weight of a HS 601 propellant tank given in Reference 5 is calculated for comparison. This surface tension tank, fabricated from $6 \mathrm{AL}-4 \mathrm{~V}$ titanium alloy has a 
volume of $0.368 \mathrm{~m}^{3}$, an operating pressure of $1790 \mathrm{kPa}$, and a mass of $12.1 \mathrm{~kg}$. The calculated mass by this equation is $12.2 \mathrm{~kg}$, showing excellent agreement for this typical flight type tank.

The pressurant tank is modeled by a carbon composite overwrapped pressure vessel and its mass is given by the following equation:

$$
M_{m^{\prime}}=1.2+\rho_{\text {liner }} v_{\text {liner }}+\rho_{\text {wrut }} v_{\text {wnip }}(\mathrm{kg})
$$

where the constant (1.2) again accounts for the reinforced inlet and outlet fittings as in Reference 4. A spherical tank with the wall thickness much less than the tank diameter, can then be put in the form:

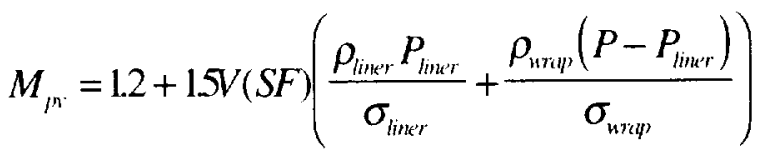

where

$$
P_{\text {liner }}=\frac{4 \sigma_{\text {liner }} t_{\text {liner }}}{D(S F)}
$$

$\mathrm{V}=\operatorname{tank}$ volume $\left(\mathrm{m}^{3}\right)$

$\mathrm{D}=$ tank diameter $(\mathrm{m})$

$\mathrm{SF}=$ safety factor

$\rho_{\text {liner }}=$ tank liner material density $\left(\mathrm{kg} / \mathrm{m}^{3}\right)$

$\mathrm{P}_{\text {liner }}=$ maximum operating pressure of the liner $(\mathrm{kPa})$

$\sigma_{\text {liner }}=$ tank liner material ultimate tensile stress $(\mathrm{kPa})$

$\mathrm{t}_{\text {liner }}=$ tank liner thickness $(\mathrm{mm})$

$\rho_{\text {wrap }}=$ composite overwrap material density $\left(\mathrm{kg} / \mathrm{m}^{3}\right)$

$\sigma_{\text {wrap }}=$ composite overwrap material ultimate tensile stress $(\mathrm{kPa})$

This model is anchored using the tank given in Reference 6. This tank has a volume of $0.0673 \mathrm{~m}^{3}$, an operating pressure of $31 \mathrm{MPa}$ and a safety factor of 1.5 . It has a $0.50 \mathrm{~mm}$ thick titanium liner with a $5.61 \mathrm{~mm}$ thick carbon composite overwrap. The fiber has a tensile strength of $5.5 \mathrm{MPa}$ and the overwrap has a density of $1800 \mathrm{~kg} / \mathrm{m}^{3}$. The composite overwrap material ultimate tensile strength is anchored at $0.94 \mathrm{MPa}$ ( $17 \%$ of the fiber tensile strength) using the operating pressure and overwrap thickness of the tank given in Reference 6. Using this equation the weight of the pressurant tank given in Reference 6 is calculated to be $11.1 \mathrm{~kg}$, which compares favorably with the given mass of $10.0 \mathrm{~kg}$.

Earth storable propulsion system component masses are supplied by vendors for the NEAR propulsion system and are given in Table 1. Some of the unit masses given are weighted averages of several sizes of components in order to have a generic mass for the model. The component quantities for the NEAR propulsion system are derived from the propulsion system hydraulic schematic given in Reference 2 . Their cumulative mass is given in Table 1 
in the column marked Earth Storable System. The pro sulsion system on NEAR, as given in Reference 2, includes three fuel tanks, two oxidizer tarks, and one pressurant tank along with these feed system components.

In the model, the mass injected by the launch vehicle is $805 \mathrm{~kg}$. The NEAR propulsion system supplies an axial $\Delta V=1176 \mathrm{~m} / \mathrm{sec}$ at a specific impulse of $313 \mathrm{sec}$ using NTO and $\mathrm{N} 2 \mathrm{H} 4$ propellants. A $\Delta \mathrm{V}=184 \mathrm{~m} / \mathrm{sec}$ for attitude control is supplied by monopropellant $\mathrm{N} 2 \mathrm{H} 4$ at a specific impulse of $234 \mathrm{sec}$. The helium pressurant is tanked at $30 \mathrm{MPa}$ and is assumed to blow down at a slow rate such that isothermal conditions at $25^{\circ} \mathrm{C}$ exist locally. A final pressure of $1.7 \mathrm{MPa}$ exists when all of the propellants are expended. A summary of the propulsion stage mass as determined by the model is given in Table 2 showing a good comparison with the mass summary given in Reference 2. Note that Reference 2 gives the masses in terms of subassemblies and does not call out a specific mass for lines \& fittings. The close agreement between the model and the actual propulsion system is predicated on several constants assumed in the model (as shown in Table 2). These constants serve to anchor the model and will remain fixed in subsequent propellant comparisons.

\section{Propellant Selection}

Table 3 lists the propellants selected for evaluation in this study. They include the state-of-art Earth storable propellants, hydrocarbons and metal hydride fuels, and several oxidizers. Hydrocarbon fuels are grouped into the following categories: a) alcohols and ethers, b) amines, c) saturated hydrocarbons, d) unsaturated hydrocarbons, e) ring hydrocarbons, and f) strained ring hydrocarbons.

Hydrocarbon fuels were selected against the criteria that they are liquid at both ground and near-Earth ambient space conditions. That is, those were selected that had a freezing point less than $-45^{\circ} \mathrm{C}$ and a boiling point above $20^{\circ} \mathrm{C}$. Table 3 shows the freezing and boiling points of all the propellants evaluated in this study. Note that the state-of-art NTO and N2H4 are liquid on the ground, but require heating in space $t c$ prevent them from freezing.

Along with freezing point and boiling point data given in Table 3 , the propellant storage density is also given. The effect of this propellant storage density feeds into propellant storage volume and thus into propulsion system dry mass.

Another criteria that was used in the selection of propellants involved an assessment of its ease of handling. In addition to being stable and insen itive to shock, the propellants had to represent less of a toxicity hazard than the state-of-art propellants. The rationale is that a less toxic propellant will require less costly procedures and apparatus for its handling. But, as discussed in Reference 7, the assessment of a propellar t's toxicity is not straightforward. In that study toxicity was based on the time weighted average (TWA) of the vapor concentration exposure limit (threshold level value) of the propellant. Table 3 lists this TWA value for the propellants used in this study, as well as their carcinogenicity. These data were obtained from vendor supplied material safety data sheets, although for some propellants, no TWA data was 
supplied. Note that the state-of-art propellants are highly toxic and one (monomethylhydrazine) is listed as mutagenic. Note, also, that the metal hydride, diborane, violates both the Earth storable and toxicity criteria. It was selected as a high performance option.

The oxidizers chosen for evaluation are also shown in Table 3. Liquid oxygen (LOX) was chosen because it has no toxicity limit, but it must be handled as a mild cryogen on Earth, as indicated by its low boiling point. In order to give a fair assessment of using LOX as the oxidizer on a spacecraft, an assessment of the need for cryogenic components and their mass is conducted. A survey of available vendor information for cryogenic component masses was conducted in Reference 8 . An estimate of the mass of multi-layer tank insulation indicates that it is negligible compared to the tank mass. Therefore, the tank models remain the same in this study. The cryogenic propellants can be loaded on the launch pad and topped off just prior to launch. The fairing can be purged with dry nitrogen to avoid frost buildup on the tanks. Only feed system components in contact with the cryogen on the launch pad are given cryogenic component masses. The feed system component masses along with the quantities used and their cumulative mass are given in Table 1 for a one cryogen type propulsion system on a NEAR type mission. These components have a mass of $28.06 \mathrm{~kg}$ compared to the $23.52 \mathrm{~kg}$ for a non-cryogen type propulsion system. Similar data for a two cryogen type propulsion system is also given in Table 1, showing a cumulative mass for feed system components of $33.75 \mathrm{~kg}$.

LOX was evaluated with all of the fuels selected. The use of LOX dictates the development of highly reliable ignition systems. Catalyst type ignition systems are especially desirable and fuel cell reformer technology may be applicable. The proposed approach is to reform the fuel into hot gases which auto-ignite with the LOX. This technology remains to be demonstrated for this application, but is assumed to exist without weight penalty over the state-of-art systems in the comparisons of this paper.

The second oxidizer chosen is high concentration $90 \%$ hydrogen peroxide ${ }^{10}(\mathrm{H} 2 \mathrm{O} 2)$. There is flight experience using this propellant as a monopropellant dating back to the Mercury spacecraft, but it was subsequently displaced by higher performing hydrazine. Note that $\mathrm{H} 2 \mathrm{O} 2$ does not meet the low freezing point selection criteria of this paper and has rather high toxicity (low TWA exposure limit). Its use on spacecraft sets thermal control requirements on the spacecraft similar to NTO. The third oxidizer chosen is $82 \%$ hydroxylammonium nitrate $^{11.12}$ (HAN). This oxidizer has good thermal properties and low toxicity in tests to date. Both $\mathrm{H} 2 \mathrm{O} 2$ and $\mathrm{HAN}$ can be decomposed exothermically with a catalyst. The resulting gases can be injected for autoignition with the fuel. In this study, $\mathrm{H} 2 \mathrm{O} 2$ and $\mathrm{HAN}$ were evaluated with JP-10 only for comparison to LOX.

The final oxidizer chosen for evaluation is oxygen difluoride ${ }^{13}$. This oxidizer does not meet the Earth storability criteria and must be handled as a mild cryogen on the ground. It is also highly toxic and does not improve on the toxicity issue of state-of-art propellants, however, it represents a high performance option. It is chosen for evaluation with diborane because they are hypergolic and have similar thermal and toxicity handling requirements. 


\section{Engine Performance}

The theoretical performance of the selected propellant combinations were calculated using the JANNAF performance prediction code ${ }^{14}$. To speed the calculation, the one-dimensional kinetics (ODK) performance of each propellant combination was calculated and a percentage of the peak value was used. Test data from a LOX/N2H4 engine ${ }^{15}$ was used to determine this percentage. This data was for a $1000 \mathrm{~N}$ engine with an area ratio of 200:1, operating at a chamber pressure of $1550 \mathrm{kPa}$ and a mixture ratio of 0.8 . This engine has a specific impulse of $351 \mathrm{sec}$, compared to the ODK peak value of $372 \mathrm{sec}$. The experimental performance, then, was $94 \%$ of the peak ODK value. The losses included in the $94 \%$ include nozzle divergence and boundary layer losses along with the combustion efficiency. This performance is shown as a data point on Figure 1 along with the theoretical prediction curves based on onedimensional equilibrium (ODE), one-dimensional kinetics (ODK), and one dimensional frozen (ODF) nozzle flow. The axial engine performance prediction in this paper, then, is set at $94 \%$ of the theoretical ODK peak performance and this peak also establishes the MR.

The theoretical ODE, ODK, and ODF performance for the propellant combinations selected for evaluation in this paper are given in Table 4. These values are calculated for $450 \mathrm{~N}$ thrust class engines at a chamber pressure of $650 \mathrm{kPa}$ and an area ratio of $200: 1$. Recombination kinetics data was not available for boron compounds, so the ODK calculation for LOX/Diborane and OF2/Diborane were omitted. The axial thruster performance estimates, set at $94 \%$ of the ODK peak, are given in Table 5. The ACS thruster performance estimates are also shown in the Table 5 and are based on a similar estimate for a 30:1 area ratio nozzle. The ODF peak value is used for the propellant combination with diborane. About $9 \mathrm{sec}$ is subtracted from this peak to be conservative:

\section{Model Results}

Model results are summarized in Table 6 and presented in terms of science payload in Figure 2. The model of the SOA system predicts an injected satellite mass of $506.6 \mathrm{~kg}$ and a propulsion system dry mass of $120.4 \mathrm{~kg}$. As discussed earlier, this is in good agreement with the actual flight system. The science payload mass is $55 \mathrm{~kg}$ leaving $315.4 \mathrm{~kg}$ for power, GN\&C, and its associated structure. Some metrics on the SOA propulsion system are obtained from the model. For example, a $1 \mathrm{sec}$ increase in the thruster Isp (both axial and ACS) yields a $1 \mathrm{~kg}$ increase in the $55 \mathrm{~kg}$ science payload. A $7.7 \% \mathrm{i}$ icrease in propellant density (both oxidizer and fuel) delivers a $1 \mathrm{~kg}$ increase in payload by reducing propulsion system dry mass. In order to increase the axial delta- $\mathrm{V}$ by $1 \%, 2.6 \mathrm{~kg}$ are subtracted from the science payload. These metrics vary somewhat with propulsion system.

The model was used first to predict the effect of advanced engine technology on the NEAR propulsion system. Iridium-coated rhenium chamber materials are nearing maturity for use with Earth storable propellants, offering higher performance than state-of-art (SOA)

silicide-coated niobium chambers. The use of an advanced rhenium engine ${ }^{16}$, with an increase in performance to $328 \mathrm{sec}$, results in an injected satellite mass of $515.5 \mathrm{~kg}$, a propulsion 
system dry mass of $117.7 \mathrm{~kg}$, and a science payload of $67.0 \mathrm{~kg}$. This gives a net increase in science payload of $12 \mathrm{~kg}$, that is, a $22 \%$ increase over the baseline value of $55 \mathrm{~kg}$.

The model was also used with a SOA NTO/MMH system with a $312 \mathrm{sec}$ axial engine and a $293 \mathrm{sec}$ ACS bipropellant engine. These ACS engines are readily available in the $22 \mathrm{~N}$ class but not in the $3.5 \mathrm{~N}$ class used for precision pointing. Assuming that there is a GN\&C solution to this issue, the use of this propulsion system could have added an additional $10.4 \mathrm{~kg}$ to the science payload for a total of $65.4 \mathrm{~kg}$. This increase is due entirely to the increased performance of a bipropellant ACS system. This system must be used as a baseline for comparisons with the other bipropellant ACS systems used in this study.

Advanced NTO/MMH engines ${ }^{17}$ have been demonstrated with $321 \mathrm{sec}$ axial engine performance and $305 \mathrm{sec}$ ACS performance. The use of these engines would add an additional $9.2 \mathrm{~kg}$ to the science payload for a total of $74.6 \mathrm{~kg}$ as noted in Table 6.

A summary of model prediction results for the propellant combinations selected for evaluation in this study is given in Table 7 and also presented in terms of science payload in Figure 2. The first system is LOX/Hydrazine operating at SOA pressures with a monopropellant ACS system. The propulsion system dry mass as shown in Table $7 \mathrm{a}$ is $125.0 \mathrm{~kg}$ due to the use of cryogenic components. The science payload estimated for this system is $67.8 \mathrm{~kg}$, a $12.8 \mathrm{~kg}$ increase over the $55.0 \mathrm{~kg}$ SOA baseline. Note, however, that a similar performance is obtained with the advanced NTO/N2H4 system shown in Table 6. Since the performance of the ACS system has a significant impact on mission performance, a LOX/Hydrazine bipropellant ACS system with a performance of $325 \mathrm{sec}$ is evaluated and shown as the second entry of Table $7 \mathrm{a}$. This propulsion system has a dry mass of $121.9 \mathrm{~kg}$ and delivers a payload of $83.4 \mathrm{~kg}$.

The third entry in Table 7a is for a LOX/Ethanol system. This is the propellant combination favored in an early LOX/Hydrocarbon auxiliary propulsion study ${ }^{18}$. This system gives a payload capability of only $60.2 \mathrm{~kg}$. It offers little new payload capability, but, is completely nontoxic and may be useful in reducing total mission cost. The fourth propellant combination uses a fuel from the amine group. Methylamine is moderately toxic, as shown in Table 3 and has a boiling point that requires dry ice chilling on the launch pad. It has a fairly high axial engine performance with LOX $(337 \mathrm{sec})$. Chemical equilibrium calculations indicate that it decomposes to methane, hydrogen and nitrogen without soot formation and may be useful as a low performing monopropellant for precision pointing. This combination offers a payload capability of $75.0 \mathrm{~kg}$ along with reduced toxicity in comparison with hydrazine.

The system performance of LOX/Pentane is given as $70.8 \mathrm{~kg}$ of payload in Table $7 \mathrm{a}$. This is $10.6 \mathrm{~kg}$ more than LOX/Ethanol with similar toxicity characteristics. Going to an unsaturated hydrocarbon such as 1-Pentene offers no improvement at $70.2 \mathrm{~kg}$ of payload. One of the high density fuels (JP-10) developed for air breathing engines ${ }^{19}$ is evaluated to provide $67.9 \mathrm{~kg}$ of payload. Its higher density does not offset its lower performance in comparison with Pentane. The second entry in Table $7 \mathrm{~b}$ is quadricyclane, a strained ring compound identified as a potential rocket propellant in the Air Force high energy density matter (HEDM) program ${ }^{20}$. It 
offers a payload capability of $72.1 \mathrm{~kg}$, which is the best performance of the room temperature hydrocarbons.

With $90 \%$ Hydrogen Peroxide/JP10, a payload of $57.0 \mathrm{~kg}$ is possible. It offers the same payload capability as the system which was flown and has much lower propellant toxicity. The $82 \%$ HAN $/ \mathrm{JP}-10$ system only offers a $10.1 \mathrm{~kg}$ payload, making it not a contender for this class of missions without a reduction in the delta- $\mathrm{V}$ requirement. The final two propellant combinations are high performance options in which both propellants are cryogens.

Significant new performance capability is offered with payloads of $94.3 \mathrm{~kg}$ and $107.5 \mathrm{~kg}$ for LOX/Diborane and OF2/Diborane, respectively. However, both propellants would require handling procedures and apparatus as elaborate as the SOA propellants, and complicated further by their cryogenic nature.

\section{Conclusions}

The performance of the on-board propulsion system is evaluated for its effect on science payload mass in a class of missions such as NEAR in the Discovery Program. The effect of propellant performance and density is evaluated for its ability to increase delivered payload mass. An increase in performance, decreases propellant mass and an increase in propellant density, decreases propulsion system dry mass. A propulsion system dry mass model is developed and anchored on the NEAR flight system. Metrics on the state-of-art propulsion system are obtained from the model. For example, a $1 \mathrm{sec}$ increase in the thruster Isp (both axial and ACS) yields a $1 \mathrm{~kg}$ increase in the $55 \mathrm{~kg}$ science payload. It takes a $7.7 \%$ increase in propellant density (both oxidizer and fuel) to deliver the same $1 \mathrm{~kg}$ increase in payload by reducing propulsion system dry mass. In order to increase the axial delta- $\mathrm{V}$ by $1 \%, 2.6 \mathrm{~kg}$ is subtracted from the science payload.

This model is used to evaluate the performance of liquid oxygen, hydrogen peroxide, hydroxylammonium nitrate, and oxygen difluoride oxidizers with hydrocarbon and metal hydride fuels. Results of the propellants evaluated indicate that the state-of-art, Earth storable propellants with high perfor-mance rhenium engine technology has performance capabilities that can only be exceeded by liquid oxygen/diborane and oxygen difluoride/diborane propellant combinations. Nontoxic propellant combinations can only offer significantly lower ground operations costs. Propel-lant combinations of LOX/hydrocarbons offer science payload delivery similar to the advanced Earth storable technology using rhenium rockets. The propellant combination, $90 \%$ hydrogen peroxide/JP-10 offers science payload delivery similar to that of state-of-art Earth storable propellants $(57 \mathrm{~kg})$, while $82 \% \mathrm{HAN} / \mathrm{JP}-10$ would only deliver a science payload of only $10.1 \mathrm{~kg}$. Propellant combinations which outperform the advanced Earth storable systems include LOX/Hydrazine with a science payload of $83.4 \mathrm{~kg}$, LOX/Diborane with a science payload of $94.3 \mathrm{~kg}$ and $\mathrm{OF}_{2} /$ Diborane with a science payload of $107.5 \mathrm{~kg}$. 


\section{References}

1. Bruegge, R., "The Discovery Program - A New Approach to Planetary Exploration". AIAA 93-4090. AIAA Space Programs and Technologies Conference. Huntsville, AL 1993.

2. Wiley, S., Herhert, G., and Mosher, L.. "Design and development of the NEAR Propulsion System", AIAA 95-2977, $31^{\text {st }}$ AIAA/ASME/SAE/ASEE Joint Propulsion Conference, San Diego, July 1995.

3. Santo, A. And Dunham, D., "Near-Earth Asteroid Rendezvous Project", AIAA 93-4089. AIAA Space Programs and Technologies Conference, Huntsville, AL 1993.

4. Smith, P. and Horton, M., "Advanced Propulsion Systems for Geostationary Spacecraft - Study Results". AIAA 84-1230, 20th AIAA/SAE/ASME Joint Propulsion Conference, Cincinnati, June 1984.

5. Tam, W., Lay, W., Hersh, M., Jaekle. D., and Epstein, S., "Design. Development, Qualification, and Manufacture of the HS 601 Propellant Tank". AIAA 96-2748, 32nd AIAA/ASME/SAE/ASEE Joint Propulsion Conference, Lake Buena Vista, July 1996.

6. Kawahara, G. And McClesky, S.. "Titanium-Lined. Carbon Composite Overwrapped Pressure Vessel". AIAA 96-275I, 32nd AIAA/ASME/SAE/ASEE Joint Propulsion Conference, Lake Buena Vista, July 1996.

7. Cort. R., Hurlburt. E., Riccio, J., and Sanders, J., "Non-Toxic On-Orbit Propulsion for Advanced Space Vehicle Applications", AIAA 95-2974, $31^{\text {st }}$ AIAA/ASME/SAE/ASEE Joint Propulsion Conference, San Diego, July 1995.

8. "Study of Low Gravity Propellant Transfer, Final Report", NASA-CR-123947, June 1972.

9. Dicks, A. L., "Hydrogen Generation from Natural Gas for the Fuel Cell Systems of Tomorrow", Journal of Power Sources, Vol. 61, pp113-124, 1996.

10. Rusek, J. J., "New Decomposition Catalysts and Characterization Techniques for Rocket Grade Hydrogen Peroxide", Journal of Propulsion and Power, Vol. 12. No. 3, pp574-579, May-June 1996.

11. Jankovsky, R. S., "HAN-Based Monopropellant Assessment for Spacecraft", AIAA 96-2863, 32nd AIAA/ASME/SAE/ASEE Joint Propulsion Conference, Lake Buena Vista, July 1996.

12. Dowler, W., Moran, C., Frisbee, R., Strand. L., Ferraro, N., Carlson, R., Beaudet, R., and Maynard, D., "Liquid Propellant 1846 Handbook", JPL D-8978, March 1992.

13. Riebling, R. Powell, W. Young. D., Rowley. R., and Oshiro, R., "A Survey of the Current Status of Thrust Chamber Technology for Oxygen Difluoride/Diborane Propellants", AIAA $70-717,6^{\text {th }}$ AIAA Propulsion Joint Specialist Conference, San Diego, CA June 1970.

14. Nickerson, G., Coats, D., Dang, A., Dunn, S., and Kehtarnavaz, "Two-Dimensional Kinetics (TDK) Nozzle Performance Computer Program", Contract NAS8-36863.

15. Chazen, M. and Mueller, T., "A Summary of the Space Storable Rocket Technology Program". AIAA 95-2940, 31 st AIAA/ASME/SAE/ASEE Joint Propulsion Conference, San Diego, July 1995.

16. Chazen, M. and Sicher, D., "High Pressure Earth Storable Rocket Technology Program Summary". AIAA 95-2939, $31^{\text {st }}$ AIAA/ASME/SAE/ASEE Joint Propulsion Conference, San Diego, July 1995

17. Rosenberg, S. And Schoenman, L., "New Generation of High-Performance Engines for Space Propulsion". Journal of Propulsion and Power, Vol. 10, No. I, Jan.-Feb 1994.

18. Orton. G. And Mark, T., "LOX/Hydrocarbon Auxiliary Propulsion for the Space Shuttle Orbiter", J. of Spacecraft, Vol. 21, No. 6, pp580-586, 1984.

19. Burdette, G., Lander, H., and McCoy, J., "High Energy Fuels for Cruise Missiles", AIAA 78-267. AIAA $16^{\text {th }}$ Aerospace Sciences Meeting. Huntsville,AL, January 1978.

20. Wucherer, E. and Cabrera, A.. "Chemical, Physical and Hazards Properties of Quadricyclane". CPIA Pub.642. pp241-249, April 1996. 
Table 1.-Propulsion system component masses used in the model along with quantities used in a NEAR type propulsion system and their cumulative mass.

\begin{tabular}{|c|c|c|c|c|c|c|c|}
\hline \multirow[b]{2}{*}{ Component } & \multirow[b]{2}{*}{\begin{tabular}{|l} 
Unit \\
Mass
\end{tabular}} & \multicolumn{2}{|c|}{$\begin{array}{l}\text { Earth Storable } \\
\text { System }\end{array}$} & \multicolumn{2}{|c|}{ Ore Cryogen System } & \multicolumn{2}{|c|}{$\begin{array}{l}\text { Two Cryogen } \\
\text { system }\end{array}$} \\
\hline & & Quantity & \begin{tabular}{|l|} 
Total \\
Mass
\end{tabular} & Quantity & Total Mass & Quantity & $\begin{array}{l}\text { Total } \\
\text { Mass }\end{array}$ \\
\hline & $\mathrm{kg}$ & & $\mathrm{kg}$ & & $\mathrm{kg}$ & & $\mathrm{kg}$ \\
\hline Axial Thruster & 4.20 & 1 & 4.20 & 1 & 4.20 & 1 & 4.20 \\
\hline ACS Thruster & 0.42 & 11 & 4.62 & 11 & 4.62 & 11 & 4.62 \\
\hline Pyro Valves & 0.15 & 0 & 0.00 & 0 & 0.00 & 0 & 0.00 \\
\hline Manual Valves & 0.22 & 4 & 0.88 & 2 & 0.44 & 0 & 0.00 \\
\hline Check Valves & 0.22 & 5 & 1.10 & 3 & 0.66 & 1 & 0.22 \\
\hline Latch Valves & 0.75 & 9 & 6.75 & 7 & 5.25 & 4 & 3.00 \\
\hline Relief Valves & 0.34 & 4 & 1.36 & 2 & 0.68 & 0 & 0.00 \\
\hline Filters & 0.13 & 8 & 1.04 & 8 & 1.04 & 8 & 1.04 \\
\hline Regulator & 1.20 & 1 & 1.20 & 1 & 1.20 & 1 & 1.20 \\
\hline Cryo Pyro Valves & 0.45 & 0 & 0.00 & 0 & 0.00 & 0 & 0.00 \\
\hline Cryo Check Valves & 0.45 & 0 & 0.00 & 2 & 0.90 & 4 & 1.80 \\
\hline Cryo Manual Valves & 0.45 & 0 & 0.00 & 2 & 0.90 & 5 & 2.25 \\
\hline Cryo Latch Valves & 1.45 & 0 & 0.00 & 2 & 2.90 & 5 & 7.25 \\
\hline Cryo relief Valves & 1.45 & 0 & 0.00 & 2 & 2.90 & 4 & 5.80 \\
\hline Pressure Transducers & 0.45 & 5 & 2.25 & 5 & 2.25 & 5 & 2.25 \\
\hline Thermocouples & 0.01 & 12 & 0.12 & 12 & 0.12 & 12 & 0.12 \\
\hline Total Component Mass & & & 23.52 & & 28.06 & & 33.75 \\
\hline
\end{tabular}

Table 2.-Comparison of the NEAR propulsion system mass as determined by the model with the flight mass given in Keference 2.

\begin{tabular}{|l|r|r|}
\hline & Model & $\begin{array}{l}\text { Flight Mass } \\
\text { (Ref. 2) }\end{array}$ \\
\hline & \multicolumn{1}{c|}{$\mathrm{kg}$} & \multicolumn{1}{c|}{$\mathrm{kg}$} \\
\hline Propellant Mass + Contingency (5\%) & 313.4 & \multicolumn{2}{|c|}{315.1} \\
\hline Axial Propellant & 256.2 & - \\
\hline ACS Propellant & 42.3 & \multicolumn{1}{|c|}{-} \\
\hline Contingency (5\%) & 14.9 & - \\
\hline Propulsion System Dry Mass & 120.4 & 121.0 \\
\hline Residuals (1\%) & 3.0 & 3.0 \\
\hline Component Dry Mass Total & 117.4 & 118.0 \\
\hline Fuel Tanks & 9.6 & 23.4 \\
\hline Oxidizer Tanks & 4.8 & 11.9 \\
\hline Pressurant Tanks & 4.2 & 10.1 \\
\hline Feed System Components & 23.4 & 31.3 \\
\hline Propulsion Structure (10\%) & 35.9 & 33.1 \\
\hline Lines \& Fittings (10\%) & 35.9 & - \\
\hline Electrical Harness, Heaters, etc. (1\%) & 3.6 & 8.2 \\
\hline Pressurant Mass & 0.9 & 1.6 \\
\hline Propulsion System Wet Mass & 434.7 & 437.7 \\
\hline
\end{tabular}


Table 3.-Propellant candidates chosen for evaluation in this mission study.

\begin{tabular}{|c|c|c|c|c|c|c|}
\hline NAME & FORMULA & F.P. & B.P. & DENSITY & TWA & Carcinogen \\
\hline & & ${ }^{\circ} \mathrm{C}$ & ${ }^{\circ} \mathrm{C}$ & $\mathrm{kg} / \mathrm{m} 3$ & $\mathrm{ppm}$ & \\
\hline \multicolumn{7}{|l|}{ STATE-OF-ART } \\
\hline Nitrogen Tetroxide & $\mathrm{N} 2 \mathrm{O} 4$ & -11 & 21 & 1431 & 3 & $\mathrm{NO}$ \\
\hline Anhydrous Hydrazine & $\mathrm{N} 2 \mathrm{H} 4$ & 2 & 113 & 1004 & 0.1 & NO \\
\hline Monomethylhydrazine & $\mathrm{CH} 6 \mathrm{~N} 2$ & -52 & 88 & 874 & 0.2 & mutagenic \\
\hline \multirow{2}{*}{\multicolumn{7}{|c|}{ HYDROCARBONS }} \\
\hline & & & & & & \\
\hline (Alcohols \& Ethers) Ethanol & $\mathrm{C} 2 \mathrm{H} 6 \mathrm{O} 1$ & -114 & 78 & 789 & 1000 & NO \\
\hline (Amines) Methylamine & $\mathrm{CH} 5 \mathrm{~N}$ & -92 & -29 & 769 & 5 & $\mathrm{NO}$ \\
\hline (Saturated $\mathrm{HC}$ ) Pentane & $\mathrm{C} 5 \mathrm{H} 12$ & -130 & 36 & 626 & 600 & NO \\
\hline (Unsaturated $\mathrm{HC}$ ) 1-Pentene & $\mathrm{C} 5 \mathrm{H} 10$ & -165 & 29 & 640 & $?$ & $\mathrm{NO}$ \\
\hline (Ring Compounds) JP-10 & $\mathrm{C} 10 \mathrm{H} 16$ & -79 & 186 & 940 & $?$ & NO \\
\hline (Strained Ring $\mathrm{HC}$ ) Quadricyclane & $\mathrm{C} 7 \mathrm{H} 8$ & -44 & 108 & 985 & $?$ & $?$ \\
\hline \multicolumn{7}{|l|}{ METAL HYDRIDES } \\
\hline Diborane & $\mathrm{B} 2 \mathrm{H} 6$ & -165 & -92 & 437 & 0.1 & NO \\
\hline & & & & & & \\
\hline \multicolumn{7}{|l|}{ OXIDIZERS } \\
\hline Liquid Oxygen & $\mathrm{O} 2$ & -218 & -183 & 1149 & None & NO \\
\hline $90 \%$ Hydrogen Peroxide & $\mathrm{H} 6.82 \mathrm{O} 5.82$ & -11 & 141 & 1390 & 1 & $\mathrm{NO}$ \\
\hline $82 \%$ Hydroxylammonium Nitrate & $\begin{array}{l}\mathrm{H} 5.42 \mathrm{~N} 1.71 \mathrm{O} \\
4.42\end{array}$ & -64 & 124 & 1520 & $?$ & NO \\
\hline Oxygen Difluoride & OF2 & -224 & -145 & 1521 & 0.1 & $\mathrm{NO}$ \\
\hline
\end{tabular}

Table 4.- Theoretical performance of selected propellant combinations at $650 \mathrm{kPa}$ chamber pressure, $450 \mathrm{~N}$ thrust class, and 200:1 area ratio.

\begin{tabular}{|l|r|r|r|r|r|r|}
\hline PROPELLANT COMBINATION & \multicolumn{2}{|c|}{ ODE peak } & \multicolumn{2}{c|}{ ODK peak } & \multicolumn{2}{c|}{ ODF peak } \\
\hline & \multicolumn{1}{|c|}{ MR } & \multicolumn{1}{c|}{ Isp } & \multicolumn{1}{c|}{ MR } & \multicolumn{1}{c|}{ Isp } & \multicolumn{1}{c|}{ MR } & \multicolumn{1}{c|}{ Isp } \\
\hline & & \multicolumn{1}{c|}{ sec } & & \multicolumn{1}{c|}{ sec } & & sec \\
\hline LOX/Anhydrous Hydrazine & 1.0 & 390.9 & 0.8 & 371.9 & 0.7 & 358.8 \\
\hline LOX/Ethanol & 1.9 & 367.9 & 1.6 & 341.1 & 1.5 & 329.8 \\
\hline LOX/Methylamine & 2.2 & 386.3 & 1.8 & 358.5 & 1.6 & 346.5 \\
\hline LOX/JP-10 & 2.6 & 379.9 & 2.2 & 349.2 & 2.2 & 333.2 \\
\hline LOX/Pentane & 3.0 & 383.7 & 2.6 & 354.9 & 2.2 & 340.7 \\
\hline LOX/1-Pentene & 2.8 & 384.4 & 2.4 & 354.7 & 2.2 & 339.6 \\
\hline LOX/Quadricyclane & 2.2 & 385.6 & 2.0 & 352.8 & 1.8 & 335.8 \\
\hline $90 \%$ Hydrogen Peroxide/JP-10 & 7.0 & 333.0 & 7.0 & 321.7 & 6.0 & 317.9 \\
\hline $82 \%$ HAN/JP-10 & 12.0 & 280.0 & 11.0 & 276.2 & 11.0 & 276.0 \\
\hline LOX/Diborane & 2.0 & 434.4 & - & - & 2.0 & 386.7 \\
\hline OF2/Diborane & 4.0 & 468.5 & - & - & 3.2 & 393.0 \\
\hline
\end{tabular}


Table 5.-Axial and ACS thruster performance estimates.

\begin{tabular}{|l|r|r|r|r|}
\hline PROPELLANT COMBINATION & \multicolumn{2}{|c|}{ Axial Estimate } & \multicolumn{2}{c|}{ ACS Estimate } \\
\hline & \multicolumn{1}{|c|}{ MR } & \multicolumn{1}{c|}{ Isp } & \multicolumn{1}{c|}{ MR } & \multicolumn{1}{c|}{ Isp } \\
\hline & & \multicolumn{1}{c|}{ sec } & & \multicolumn{1}{c|}{ sec } \\
\hline LOX/Anhydrous Hydrazine & 0.8 & 343 & 0.8 & 325 \\
\hline LOX/Ethanol & 1.6 & 321 & 1.6 & 302 \\
\hline LOX/Methylamine & 1.8 & 337 & 1.8 & 319 \\
\hline LOX/JP-10 & 2.2 & 328 & 2.2 & 311 \\
\hline LOX/Pentane & 2.6 & 334 & 2.6 & 316 \\
\hline LOX/1-Pentene & 2.4 & 333 & 2.4 & 316 \\
\hline LOX/Quadricyclane & 2.0 & 332 & 2.0 & 316 \\
\hline $90 \%$ Hydrogen Peroxide/JP-10 & 7.0 & 302 & 7.0 & 283 \\
\hline $82 \%$ HAN/JP-10 & 11.0 & 260 & 11.0 & 245 \\
\hline LOX/Diborane & 2.0 & 378 & 2.0 & 354 \\
\hline OF2/Diborane & 3.6 & 384 & 3.6 & 367 \\
\hline
\end{tabular}

Table 6.-Model predictions of state-of-art and advanced Earth storable propulsion system performance on a NEAR type mission in which the mass injected by the launch vehicle is $805 \mathrm{~kg}$.

\begin{tabular}{|l|r|r|r|r|}
\hline MISSION PERFORMANCE SUMMARY & NTO/N2H4 & NTO/N2H4 & NTO/MMH & NTO/MMH \\
\hline & \multicolumn{1}{|c|}{ SOA } & Advanced & \multicolumn{1}{|c|}{ SOA } & Advanced \\
\hline Axial Isp sec & 313 & 328 & 312 & 321 \\
\hline ACS Isp sec & 234 & 234 & 293 & 305 \\
\hline Propellant Density kg/m3 & 1118 & 1139 & 1154 & 1154 \\
\hline & & & & \\
\hline End of Life Mass $\sim \mathrm{kg}$ & 506.6 & 515.5 & 514.1 & 521.1 \\
\hline Propulsion system Dry Mass $\sim \mathrm{kg}$ & 120.4 & 117.7 & 118.0 & 116.1 \\
\hline Contingency Propellant (5\%) $\sim \mathrm{kg}$ & 14.9 & 14.5 & 14.5 & 14.2 \\
\hline Helium kg & 0.9 & 0.8 & 0.8 & 0.8 \\
\hline Power, GN\&C, etc., $\sim \mathrm{kg}$ & 315.4 & 315.4 & 315.4 & 315.4 \\
\hline Science Payload $\sim \mathrm{kg}$ & 55.0 & 67.0 & 65.4 & 74.6 \\
\hline & & & & \\
\hline $\begin{array}{l}\text { Propulsion System Wet Mass Fraction of } \\
\text { Satellite }\end{array}$ & 0.540 & 0.525 & 0.527 & 0.516 \\
\hline Dry Mass Fraction of Propulsion System & 0.277 & 0.279 & 0.278 & 0.280 \\
\hline
\end{tabular}


Table 7a.-Model predictions of propulsion system performance with selected propellants on a NEAR type mission in which the mass injected by the launch vehicle is $805 \mathrm{~kg}$.

\begin{tabular}{|c|c|c|c|c|c|c|}
\hline MISSION PERFORMANCE SUMMARY & $\begin{array}{l}\mathrm{LOX} \\
\mathrm{N} 2 \mathrm{H} 4\end{array}$ & $\begin{array}{l}\mathrm{LOX} / \\
\mathrm{N} 2 \mathrm{H} 4\end{array}$ & $\begin{array}{l}\text { LOX/ } \\
\text { Ethanol }\end{array}$ & $\begin{array}{l}\text { LOX/ } \\
\text { Methyla- } \\
\text { mine }\end{array}$ & $\begin{array}{l}\text { LOX/ } \\
\text { Pentane }\end{array}$ & $\begin{array}{l}\text { LOX/1- } \\
\text { Pentene }\end{array}$ \\
\hline Axial Isp sec & 343 & 343 & 321 & 337 & 334 & 333 \\
\hline ACS Isp sec & 234 & 325 & 302 & 319 & 316 & 316 \\
\hline Propellant Density $\sim \mathrm{kg} / \mathrm{m} 3$ & 1044 & 1063 & 978 & 977 & 933 & 932 \\
\hline End of Life Mass $\sim \mathrm{kg}$ & 523.8 & 535.7 & 520.8 & 531.8 & 529.8 & 529.3 \\
\hline Propulsion system Dry Mass $\sim \mathrm{kg}$ & 125.0 & 121.9 & 128.8 & 125.7 & 127.6 & 127.7 \\
\hline Contingency Propellant $(5 \%) \sim \mathrm{kg}$ & 14.1 & 13.5 & 14.2 & 13.7 & 13.8 & 13.8 \\
\hline Helium kg & 1.5 & 1.6 & 2.1 & 2.0 & 2.2 & 2.2 \\
\hline Power, GN\&C, etc., $\sim \mathrm{kg}$ & 315.4 & 315.4 & 315.4 & 315.4 & 315.4 & 315.4 \\
\hline Science Payload kg & 67.8 & 83.4 & 60.2 & 75.0 & 70.8 & 70.2 \\
\hline $\begin{array}{l}\text { Propulsion System Wet Mass Fraction of } \\
\text { Satellite }\end{array}$ & 0.524 & 0.505 & 0.533 & 0.515 & 0.520 & 0.521 \\
\hline Dry Mass Fraction of Propulsion System & 0.296 & 0.300 & 0.300 & 0.303 & 0.305 & 0.304 \\
\hline
\end{tabular}

Table 7b.-Model predictions of propulsion system performance with selected propellants on a NEAR type mission in which the mass injected by the launch vehicle is $805 \mathrm{~kg}$.

\begin{tabular}{|c|c|c|c|c|c|c|}
\hline MISSION PERFORMANCE SUMMARY & $\begin{array}{l}\mathrm{LOX} / \\
\mathrm{JP}-10\end{array}$ & $\begin{array}{l}\text { LOXI } \\
\text { Quadri- } \\
\text { cyclane }\end{array}$ & $\begin{array}{l}90 \% \\
\mathrm{H} 2 \mathrm{O} 2 / \\
\mathrm{JP}-10 \\
\end{array}$ & $\begin{array}{l}82 \% \mathrm{HAN} / \\
\mathrm{JP}-10\end{array}$ & $\begin{array}{l}\text { LOX/ } \\
\text { Dibor-ane }\end{array}$ & $\begin{array}{l}\text { OF2/ } \\
\text { Dibor-ane }\end{array}$ \\
\hline Axial Isp sec & 328 & 332 & 302 & 260 & 378 & 384 \\
\hline ACS Isp sec & 311 & 316 & 283 & 245 & 354 & 367 \\
\hline Propellant Density $\sim \mathrm{kg} / \mathrm{m} 3$ & 1074 & 1089 & 1312 & 1446 & 745 & 989 \\
\hline End of Life Mass $\sim \mathrm{kg}$ & 525.9 & 528.7 & 506.5 & 470.2 & $\overline{556.0}$ & 560.0 \\
\hline Propulsion system Dry Mass $\sim \mathrm{kg}$ & 126.5 & 125.3 & 118.5 & 127.2 & 131.3 & 123.1 \\
\hline Contingency Propellant (5\%) kg & 14.0 & 13.8 & 14.9 & 16.7 & 12.5 & 12.3 \\
\hline Helium $\sim \mathrm{kg}$ & 2.1 & 2.0 & 0.7 & 0.7 & 2.5 & 1.6 \\
\hline Power, GN\&C, etc., $\sim$ kg & 315.4 & 315.4 & 315.4 & 315.4 & 315.4 & 315.4 \\
\hline Science Payload $~-\mathrm{kg}$ & 67.9 & 72.1 & 57.0 & 10.1 & 94.3 & 107.5 \\
\hline $\begin{array}{l}\text { Propulsion System Wet Mass Fraction of } \\
\text { Satellite }\end{array}$ & 0.524 & 0.519 & 0.537 & 0.596 & 0.491 & 0.475 \\
\hline Dry Mass Fraction of Propulsion System & 0.300 & 0.300 & 0.274 & 0.265 & 0.332 & 0.322 \\
\hline
\end{tabular}




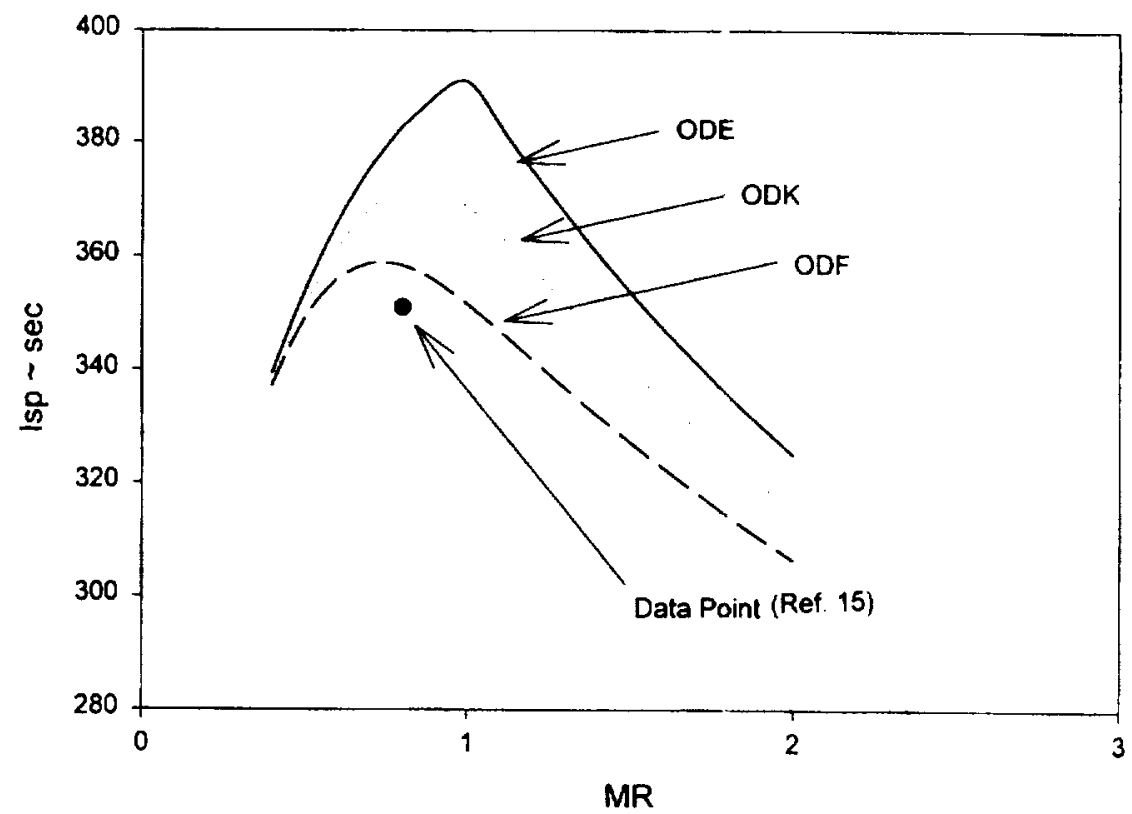

Figure 1.-Comparison of experimental data from Reference 15 with theoretical predictions for LOX/Anhydrous Hydrazine at $1550 \mathrm{kPa}$ chamber pressure, $1000 \mathrm{~N}$ thrust class, and 200:1 area ratio. Performance losses are 94\% of theoretical ODK peak.

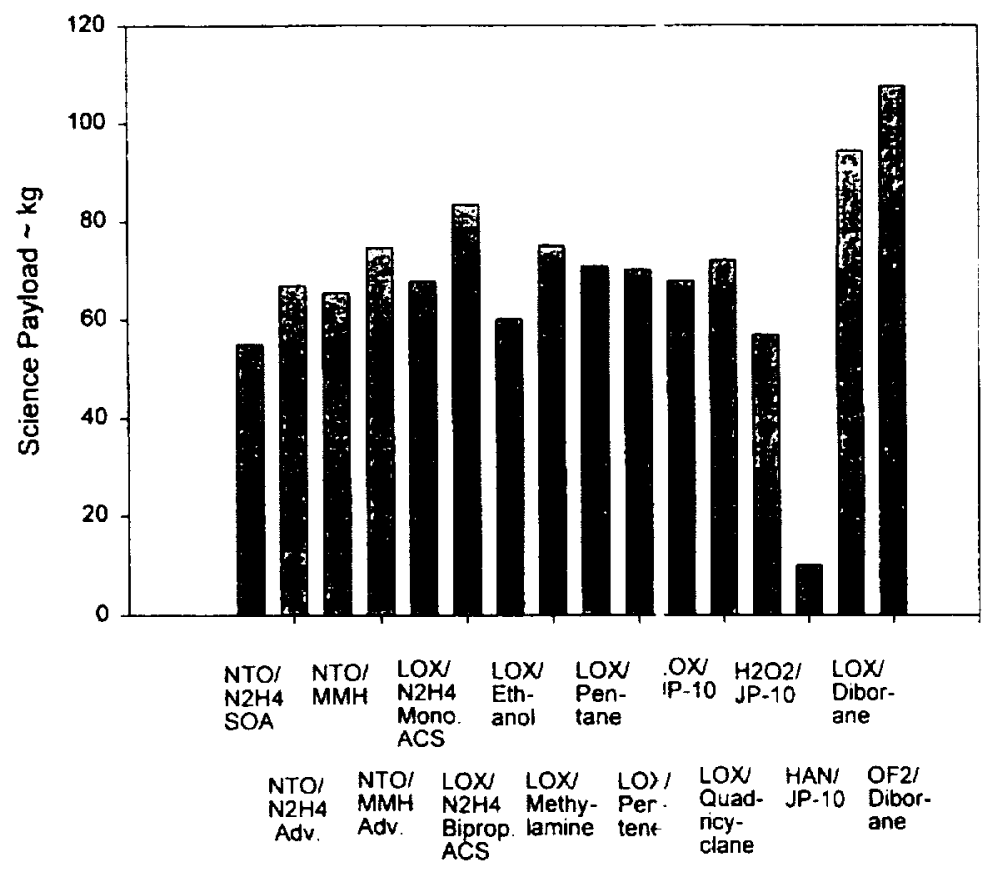

Figure 2.-Comparison of science payload for different propulsion systems on a NEAR type mis! ion 
Public reporting burden for this collection of information is estimated to average 1 hour per response, including the time for reviewing instructions. searching existing data sources, gathering and maintaining the data needed, and completing and reviewing the collection of information. Send comments regarding this burden estimate or any other aspect of this Davis Highway, Suite 1204, Arlington, VA 22202-4302, and to the Otfice of Management and Budget, Paperwork Reduction Project (0704-0188). Washington, DC 20503.

\begin{tabular}{|l|c|c|} 
1. AGENCY USE ONLY (Leave blank) & $\begin{array}{c}\text { 2. REPORT DATE } \\
\text { October } 1998\end{array}$ & $\begin{array}{c}\text { 3. REPORT TYPE AND DATES COVERED } \\
\text { Technical Memorandum }\end{array}$ \\
\hline
\end{tabular}

4. TITLE AND SUBTITLE

5. FUNDING NUMBERS

On-Board Propulsion System Analysis of High Density Propellants

6. AUTHOR(S)

Steven J. Schneider

7. PERFORMING ORGANIZATION NAME(S) AND ADDRESS(ES)

National Aeronautics and Space Administration

Lewis Research Center

Cleveland, Ohio 44135-3191

WU-6.32-1B-1B-00

9. SPONSORING/MONITORING AGENCY NAME(S) AND ADDRESS(ES)

National Aeronautics and Space Administration

Washington, DC 20546-0001

8. PERFORMING ORGANIZATION REPORT NUMBER

$E-11403$

10. SPONSORINGMONITORING AGENCY REPORT NUMBER

NASA TM-1998-208811

AIAA-98-3670

\section{SUPPLEMENTARY NOTES}

Prepared for the 34th Joint Propulsion Conference and Exhibit cosponsored by AIAA. ASME, SAE, and ASEE, Cleveland. Ohio, July 13-15, 1998. Responsible person, Steven J. Schneider, organization code 5430, (216) 977-7484.

12a. DISTRIBUTION/AVAILABILITY STATEMENT

12b. DISTRIBUTION CODE

Unclassified - Unlimited

Subject Category: 20

Distribution: Nonstandard

This publication is available from the NASA Center for AeroSpace Information, (301) 621-0390.

13. ABSTRACT (Maximum 200 words)

The impact of the performance and density of on-board propellants on science payload mass of Discovery Program class missions is evaluated. A propulsion system dry mass model, anchored on flightweight system data from the Near Earth Asteroid Rendezvous mission is used. This model is used to evaluate the performance of liquid oxygen, hydrogen peroxide, hydroxylammonium nitrate, and oxygen difluoride oxidizers with hydrocarbon and metal hydride fuels. Results for the propellants evaluated indicate that the state-of-art, Earth storable propellants with high performance rhenium engine technology in both the axial and attitude control systems has performance capabilities that can only be exceeded by liquid oxygen/hydrazine, liquid oxygen/diborane and oxygen difluoride/diborane propellant combinations. Potentially lower ground operations costs is the incentive for working with nontoxic propellant combinations.

\begin{tabular}{|c|c|c|}
\hline \multicolumn{3}{|l|}{ 14. SUBJECT TERMS } \\
\hline \multicolumn{3}{|c|}{ On-board propulsion: Satellites: Chemical rockets; System analysis } \\
\hline $\begin{array}{l}\text { 17. SECURITY CLASSIFICATION } \\
\text { OF REPORT } \\
\text { Unclassified }\end{array}$ & $\begin{array}{l}\text { 18. SECURITY CLASSIFICATION } \\
\text { OF THIS PAGE } \\
\text { Unclassified }\end{array}$ & $\begin{array}{l}\text { 19. SECURITY CLASSIFICATION } \\
\text { OF ABSTRACT } \\
\text { Unclassified }\end{array}$ \\
\hline
\end{tabular}

NSN 7540-01-280-5500

\begin{tabular}{|} 
15. NUMBER OF PAGES \\
20 \\
\hline $\begin{array}{c}\text { 16. PRICE CODE } \\
\text { A } 03\end{array}$ \\
\hline
\end{tabular}

20. LIMITATION OF ABSTRACT

Standard Form 298 (Rev. 2-89) Prescribed by ANSI Std. Z39-18 298-102 
